\title{
Introduction: Class and Christianity
}

\author{
Sarah-Jane Page, Mathew Guest and Yvette Taylor \\ Aston University; Durham University; University of Strathclyde
}

\section{Introduction}

It is widely acknowledged that social inequalities and religion are related, and yet the interconnections between religion and social class are rarely examined (McCloud 2007a, 2007b; Reiger 2013). Within the British context, this is especially striking, given the ways in which Christianity in particular has been implicated in the historical formation of social class structures and in alignments with political and economic interests throughout the modern period (Martin 1978). The Church of England has long been associated with the ruling elite, both directly in its established status and episcopal representation in the House of Lords, and also in its cultural alignment with the upper classes, so that Anglican sociality has often been a mechanism for the valorisation of behaviours characteristic of particular elite groups (Guest 2007; Guest, Olsen and Wolffe 2012). Meanwhile, evangelical Christianity has been understood as a vehicle for social mobility (Cunningham 1991). Our aim in this special issue is to revisit debates about subjectivity but in relation to a more complex, hitherto underresearched, range of Christian identities. Echoing debates about intersectionality (Taylor et al.2010), the intention is to highlight strands of selfhood that draw upon both conventionally Christian and 'secular' sources in constructing blended identities whose resonance with broader, more subtle expressions of power is thereby opened up for fresh scrutiny.

Whilst patterns connecting Christianity and social class have been noted, they have not been subject to concerted sociological treatment. This special issue aims to re-engage class with religion and to retell their mutual relevancies, changing shape, character and containment. Core issues in classical sociology, both religion and class have been marginalised topics within the broader discipline, but have recently re-emerged on the public agenda, precipitated by governmental concerns about securitisation and the integration of minority religious communities, especially Muslims, and by awareness of financial injustice in the aftermath of the economic downturn (see Rieger 2013; Tyler 2013), triggering protest and intervention among religious organisations. In $21^{\text {st }}$ century Britain inequalities are stark and government cuts place those on the fringes of society in ever-greater economic hardship. Contesting neo-liberal narratives of the sovereign consumer involves reengaging with structural inequalities, and this includes religious institutions and ideas which, assumed to be socially insignificant, can actually be strongly associated with patterns of privilege and the reinforcement of inequalities, whilst also being a major inspiration for their ideological challenge. 
Whilst religion and class have both had an inconsistent relationship with the sociological mainstream, what is of enormous significance is the near-absence of research on the intersections between class and religion. Some Marxist and feminist analyses uncritically ascribe to religious movements a tendency to disempower and emasculate vulnerable subjects, whilst less ideologically-driven treatments simply present religious norms as vehicles for class-based inequalities. Our aim is to move beyond these assumptions and present a more complex approach, one that explores the various ways in which Christianity and class interact as aspects of social identity. We ask, what do disciplinary divides make 'redundant', 'resurgent' and 'relevant' in terms of class/religion (Taylor 2012)? What might be gained by situating a classed analysis of Christianity at the intersection of disciplinary and institutional boundaries? What do patterns of distinction inflected by Christian concerns contribute to the construction of collective identities within church, academy or the public sphere?

This special issue will explore how a reconsideration of a classed Christianity in Britain generates new ways of thinking about power and social class within late modernity. Each essay brings qualitative and/or quantitative data into conversation with cutting-edge debates, offering fresh insight into current sociological thinking around class, power and identity, drawing on theoretical frameworks from classical sociology, Marxist, Bourdieusian and intersectional approaches. A number of contributors draw inspiration from Bourdieu's work, exploring how religious fields might generate distinctive forms of capital, and how such 'religious capital' might be infused with and transferable into social, cultural and economic capital conventionally located outside of religious contexts (Guest 2007; Rey 2004; Swartz 1996). Emerging scholarship has furnished a complex treatment of power as mobilised in religious settings, and yet such power is often conceived in individualised form, and rarely discussed in terms of its contexts of circulation in relation to organised Christianity. Our aim is to draw theoretical connections between power within a Bourdieusian framework and class as embodied identities, in order to properly account for the complex ways in which power and social status variously interact within contexts framed by Christian traditions. More broadly, these papers will discuss themes such as the discursive dissociation between Christianity and social class, classed and religious subjectivity, identities at the intersections of Christianity and class and the emerging formation of capitals.

Andrew McKinnon's article, 'Religion and Social Class: Theory and Method after Bourdieu', provides a broad overview of the theoretical disconnections that have been apparent in relation to sociology and social class research, offering specific insights into the value of Bourdieu's work in this regard. McKinnon focuses on the different elements of Bourdieu's work, emphasising what his book Distinction offers the study of religion and class, as well as considering his lesser-known work on religious fields. McKinnon concludes that whilst the former body of work is well-suited to class analysis and the latter to 
researching religion, there are fruitful ways of engaging these different elements of Bourdieu's ideas in undertaking an analysis of religion, with McKinnon exploring this specifically in relation to the Church of England.

Joanne McKenzie's article, '"The person God made me to be": Navigating WorkingClass and Christian Identities in English Evangelical Christianity', focuses on the experiences of evangelical working-class church leaders. The article deploys the Bourdieusian notion of the 'cleft habitus' to explore how these leaders navigate the lack of alignment experienced between their habitus and the evangelical spaces they occupy, spaces frequently constructed as middle class. McKenzie's research demonstrates that, despite the injuries of class experienced, participants remain engaged in a proactive quest for an integrated identity, both fully evangelical and fully working class.

Anna Strhan also focuses on evangelicalism, here analysing the intersections of education and social class, and the ways in which an evangelical school setting promotes particular constructions of social mobility and aspiration. Her article, 'I Want There to Be No Glass Ceiling: Evangelicals' Engagements with Class, Education, and Urban Childhoods', deploys an historical lens of Victorian philanthropism to explore socio-economic polarisation in contemporary London and how an evangelically-focused education is constructed as a means of 'saving' working-class children from future socio-economic disadvantage.

Sarah-Jane Page, using the Church of England akin to a Bourdieusian field, examines how this field becomes a site for the reproduction of privilege. Focusing on clergy husbands, she analyses how they are able to utilise the resources the Church offers to bolster their middle-class credentials, a process from which working-class spouses are specifically excluded. This analysis helps demonstrate the specific classed contours underpinning England's established Church.

In the article, 'Students' Constructions of a Christian Future: Faith, Class and Aspiration in University Contexts', Mathew Guest and Kristin Aune consider social mobility amongst Christians attending university. They examine the extent to which a Christian identity impacts on future aspirations, exploring whether Christianity is a transgressive force. Their analysis reveals that whilst Christian students negatively appraise neoliberal capitalist impulses, they reaffirm traditional notions of the family, and aspire to heteronormative futures.

Finally, Yvette Taylor explores the notions of precarity and aspiration in post-welfare times, using the intersection between religion and sexuality to explore these themes. 'Mediating Aspirant Religious-Sexual Futures: In God's Hands?', emphasises how mainly middle-class queer Christians envisage their future family life and employability. She notes a resistance to dominant narratives positioning youthful bodies as both aspirational, imbued with (queer) future potential, and failing (as 'at risk' youth). Many respondents also reject the neoliberal consensus of individualism, a position produced through their identities 
as both Christian and queer, and where heteronormative imaginings are critiqued, re-worked and re-produced.

This collection of articles revitalises the discussion of religion and class, emphasising the potential benefits of bringing class and religion into critical conversation. Although the focus here is specifically centred upon various forms of Christianity, there is much scope for developing this analysis to include other Christianities (e.g. Catholicism, Pentecostalism) and other religions (Page and Yip forthcoming). What is clear is that failing to 'see' religion within class analysis has had consequences for how patterns of privilege and disadvantage are mapped. The complex role religion plays in mediating identities has been poorly understood within sociology, and this special issue goes some way to indicating what bringing religion into the conversation can offer.

\section{References}

CUNNINGHAM, H. (1991) The Children of the Poor Oxford, Basil Blackwell.

GUEST, M. (2007) 'In Search of Spiritual Capital: The Spiritual as a Cultural Resource' In FLANAGAN, K. and JUPP, P. (eds) A Sociology of Spirituality Aldershot, Ashgate.

GUEST, M., OLSON, E. and WOLFFE, J. (2012) 'Christianity: Loss of Monopoly' In WOODHEAD, L. and CATTO, R. (eds) Religion and Change in Modern Britain London, Routledge MARTIN, D. (1978) A General Theory of Secularisation London, Basil Blackwell.

MCCLOUD, S. (2007a) Divine Hierarchies: Class in American Religion and Religious Studies Chapel Hill, The University of North Carolina Press.

MCCLOUD, S. (2007b) 'Putting Some Class into Religious Studies: Resurrecting an Important Concept' In: Journal of the American Academy of Religion, 75(4) p.840862. [doi:10.1093/jaarel/lfm068]

PAGE, S. and YIP, A. K. T. (forthcoming) Understanding Young Buddhists: Living Out Ethical Journeys Leiden, Brill.

REIGER, J. (2013) 'Introduction: Why Class Matters in Religious Studies and Theology' in RIEGER, J. (ed) Religion, Theology, and Class: Fresh Engagements after Long Silence New York, Palgrave MacMillan.

REY, T. (2004) 'Marketing the Goods of Salvation: Bourdieu on Religion' In: Religion, 34 (4) p.331343.

SWARTZ, D. (1996) 'Bridging the Study of Culture and Religion: Pierre Bourdieu's Political Economy of Symbolic Power' In: Sociology of Religion, 57(1) p.71-85. [doi:10.2307/3712005]

TAYLOR, Y., HINES, S. and CASEY, M. (eds) (2010) Theorizing Intersectionality and Sexuality London, Palgrave.

TAYLOR, Y. (2012) 'Class Encounters: Again...', Editorial, In: Social and Cultural Geography, 13(6) p.545-549. [doi:10.1080/14649365.2012.696680] 
TYLER, I. (2013) Revolting Subjects: Social Abjection and Resistance in Neoliberal Britain London, Zed Books. 